\title{
Nutraceuticals Potential of Petroselinum Crispum: A Review
}

\author{
Chauhan E S and Aishwarya J* \\ Department of Food Science and Nutrition, Banasthali University, India
}

Submission: April 09, 2018; Published: August 22, 2018

*Corresponding author: Jaya Aishwaya, Department of Food Science and Nutrition, Banasthali University, Ramanujan Niwas, Banasthali Vidyapith, Newai Tonk, Rajasthan, India, Tel: 7737116621; Email: aishwarya.jaya16@gmail.com

\begin{abstract}
Petroselinum crispum is a green biennial hedge plant which belongs to Apiaceae family indigenous to Europe and Western Asia. Flavonoids like apigenin, chrysoeriol and quercetin are chief components in Petroselinum crispum plant that decrease the oxidative damage associated with cancer, aging, atherosclerosis, ischemic damage, soreness, and neurodegenerative diseases. Leaves, seeds and roots of Petroselinum crispum are used as hepatoprotective, brain protective, anti-diabetic, analgesic, spasmolytic, immunosuppressant, anti-anemic, menorrhagia, anti-coagulant, anti-hyperlipidemic and many more diseases. This paper put a light on bioactive and nutraceuticals properties of Petroselinum crispum.
\end{abstract}

Keywords: Petroselinum crispum; Anti-oxidant; Bioactive compounds; Nutraceuticals

\section{Introduction}

Petroselinum crispum (Parsley) is an herbal plant which belongs to Apiaceae family indigenous to Europe and western Asia. Petroselinum crispum is having therapeutic potential as well as used for additives, garnishing, condiment, flavoring agents and perfume. Petroselinum crispum is also used in cosmetics industries mainly China, Mexico, South America, India and South-East Asia. In India it got cultivated in Jammu and Kashmir, Punjab, Uttrakhand,

Uttar Pradesh, Maharashtra and Karnataka states. Petroselinum crispum leaves look like coriander leaves but the taste and aroma hold opposing views. Petroselinum crispum contains small, dark seeds which content volatile oil [1]. In Britain, they prefer the curly leaves forms for culinary purposes and on the continent plain leaves varieties are preferred for garnishes and flavoring [2] (Figure 1) (Table 1).
Table1: Classification of Petroselinum crispum.

\begin{tabular}{|c|c|}
\hline Rank & $\begin{array}{c}\text { Scientific Name and (Common } \\
\text { Name) }\end{array}$ \\
\hline Kingdom & Planate \\
\hline Division & Magnoliophyta (Flowering plants) \\
\hline Super division & Spermatophyta (Seed plants) \\
\hline Class & Magnoliopsida (Dicotyledons) \\
\hline Order & Petroselinum crispum \\
\hline Family & Apiaceae / Umbelliferae \\
\hline Genus & Petroselinum J. Hill (Parsley) \\
\hline Species & $\begin{array}{c}\text { Petroselinum crispum (Mill.) Nyman ex } \\
\text { A.W. Hill (Parsley) }\end{array}$ \\
\hline
\end{tabular}
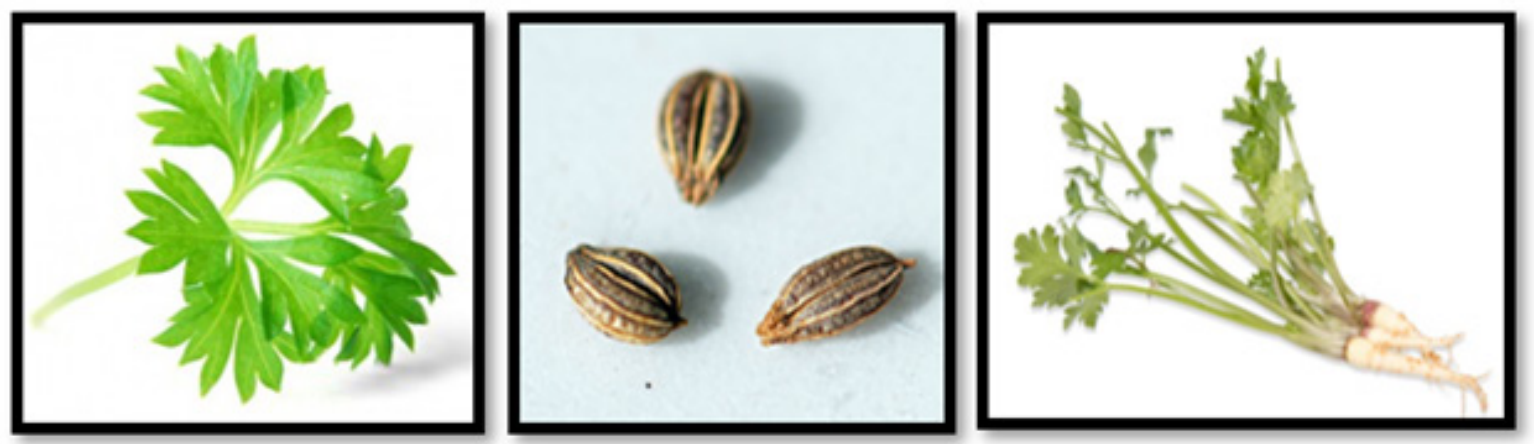

Figure 1: Leaf, Seeds and Roots of Petroselinum crispum. 
Petroselinum crispum fresh and dry leaves are rich source of phytochemical and anti-oxidant as well as its essential oils also holds important place. Many studies showed that it contains flavnoids, carotenoids, luteolin, apigenin, ascorbic acid, to cophenol and apiol are the main essential compounds. Fresh leaves helps in reducing oxidative stress in humans. It grows biennial, in the first year; it forms a rosette of tripinnate leaves $10-25 \mathrm{~cm}$ leaflets and taproot used as a food store over winter. In second year it grows a flowering stem to $75 \mathrm{~cm}$ tall with sparser leaves and flat topped $3-10 \mathrm{~cm}$ diameter umbels with number of yellowish green flowers. Petroselinum crispum seeds are ovoid 2-3mm long with prominent style remnants at the apex. The plant dries after the maturation of seeds. Petroselinum crispum root is common food in eastern and Europeans cuisines used mainly in snacks as soups, stews and casseroles.

\section{Bioactive Components}

Petroselinum crispum contains many antioxidant properties, luteolin [3], flavonoid, coumarins, tocopherol, myristicin [4], essentials oils and phenolic compounds [5]. Carotenoids, vitamin-A, B and C [6,7]; minerals like iron, zinc calcium, phosphorous are also present in Petroselinum crispum leaves [8,9]. Furanocoumarins such as psoralen, bergapten, isoimperatorin, oxypeucedanin, xanthoxin, trioxalen and angelicin are key substances of Petroselinum crispum. Flavonoids like apigenin, chrysoeriol and quercetin are chief components in Petroselinum crispum plant that decrease the oxidative damage associated to cancer, aging, atherosclerosis, ischemic damage, soreness and neurodegenerative diseases $[1,10]$. Petroselinum crispum leaves also contain n-3 omega fatty acids like linolenic and palmitic acid [11-13].

\section{Therapeutic Potential}

Traditionally Petroselinum crispum is used for menstrual disorder, emmenagogue, galactagogue [14] intestinal cramps, diarrhea and in opposition to head lice [15] and anti-cancer activity [16]. Due to the presence of bioactive compounds, Petroselinum crispum shows different pharmacological activities such hepatoprotective, brain protective, anti-diabetic analgesic and spasmolytic [17]. As well as beneficial for immunosuppressant, anti-anemic, menorrhagic, anti-coagulant, anti-hyperlipidemic, anti-hypertensive effects anti-platelet, anti-inflammatory, antihepatotoxic and anti-tumor [10,18]. Allergy similar to asthma [19], gastro protective, cytoprotective, laxative, estrogenic, diuretic, chronic bronchitis, dyspepsia and hypotensive [20,21] Alzheimer's disease, thrombosis and strokes [22] are also alleviated by Petroselinum crispum. The flavnoid myristicin contained in the plant has the properties to increase the production of estrogen which make their use relevant in menopause. Different parts of Petroselinum crispum plant are also used in curing diseases such as the roots are used in flatulence, cystitis. Leaves and stems are remedy for menstrual problems, cystitis, edema, kidney stones, prostatitis, cramps, indigestion, anorexia, arthritis and rheumatism [23]. Its leaf, seed and root are being used in eczema, controlling high blood pressure, strengthen the bladder, nose bleeding, hematoma, skin blemishes, ear ache, otitis, emenagogue favoring menstruation and alleviating its pains. Petroselinum crispum is also widely used as a galactofuge by lactating mothers to stop excessive milk production [24]. Petroselinum crispum root is taken as a treatment for flatulence, cystitis, and rheumatic conditions.

\section{Anti- neurotoxicity}

Petroselinum crispum has a protective effect against cadmium neurotoxicity and teratogenicity in albino mice. Petroselinum crispum seeds and leaves juice supplementation improves the behavior of prenatally cadmium intoxicated mice newborns and reduces neuronal aberrations in the brain caused by oxidative stress $[20,25,26]$.

\section{Anti-oxidant activity}

Adding Petroselinum crispum leaves to the diet of 14 people for one week caused significant increase in antioxidant enzymes compared with their levels in the basic diet received group. Apigenin was demonstrated to be the main compound responsible for this activity Petroselinum crispum [27,28]. Different extracts from Petroselinum crispum leaves and stems exhibited antioxidant properties in various in vitro models [29-32]. Essential oil from seed showed in vitro antioxidant activity. Apiol and myristicin are two components responsible for its antioxidant activity [13].

\section{Analgesic and spasmolytic activity}

Petroselinum crispum seed hydroalcoholic extract revealed analgesic activity in mice [33]. It also reduced $\mathrm{KCl}$ - and $\mathrm{CaCl} 2$ induced contractions on rat isolated ileum dose dependently via blocking voltage-gated calcium channels [34]. Different extracts from aerial parts demonstrated antispasmodic activity on spontaneous and acetylcholine- induced contractions of rat isolated ileum [34].

\section{Immunomodulating activity}

Essential oil from Petroselinum crispum seed suppressed humoral and cellular immune response via inhibiting splenocytes and macrophages function [35].

\section{Gastrointestinal activity}

Ethanol extract from Petroselinum crispum leaves executed beneficial effects on different models of peptic ulcer in rats via its anti-secretory and cytoprotective activity [36]. Aqeoues extract from Petroselinum hortence seeds demonstrated laxative activity in rat by significant absorption of sodium and water and also enhancing $\mathrm{Na}-\mathrm{KCl} 2$ transporter activity in the colon [37].

\section{Genitourinary system}

Methanol extract from Petroselinum crispum aerial part showed proliferative activity in estrogen-sensitive breast cancer cell line (MCF-7) equal to isoflavone glycosides from soybean. This estrogenic activity was related to flavone glycosides; 6"-acetylapiin and also aglicones; apigenin, diosmetin, and kaempferol. Furthermore, oral administration of the extract regenerated the uterus weight in ovariectomized mice and apiin and apigenin were responsible for this activity [38]. Seudomonas 
crispum oil demonstrated significant protective activity against zearalenone -induced reproductive toxicity and significantly improved testosterone level, sperm count, sperm motility and inhibited germ cells chromosomal aberrations [39]. Aqeoues extract of Pseudomonas hortense seeds exhibited diuretic effect and inhibited $\mathrm{Na}+\mathrm{K}+\mathrm{ATPase}$ activity in kidney cortex and medulla [40].

\section{Cardiovascular activity}

Petroselinum crispum leaves decreased mean blood pressure which recorded from the carotid artery in anaesthetized rats. This effect was attenuated with muscarinic receptor antagonist. It also decreased rate and amplitude of contraction on isolated rat atria which weakened by muscarinic antagonist. These data indicate hypotensive and negative inotropic and chronotropic activity of Petroselinum crispum [41]. Petroselinum crispum leaves demonstrated strong antiplatelet aggregation effect. Aglycone flavonoids; keampferol, apigenin and cosmosiin are responsible compounds for this activity. However, it did not exert inhibition on clotting activity in vitro [42-44].

\section{Antimicrobial and cytotoxic activity}

Petroselinum crispum leaves and stems possess antibacterial activity on Bacillus subtilis and Escherichia coli [32]. Hot and cold water extract from Petroselinum crispum leaves demonstrated antibacterial activity against Pseudomonas aeruginosa, Staphylococcus aureus and Staphylococcus pyogenes isolated from patient with burn infection. 7 Ethanol extract of Pseudomonas crispum leaves inhibited the growth of Lactobacillus plantarum and Leuconostoc mesenteroides [45]. The furocoumarins isolated extract from Petroselinum crispum leaves demonstrated inhibitory activity against Escherichia coli, Listeria monocytogenes, Erwinia carotovora and Listeria innocua and no inhibition against Pseudomonas fragi. Psoralen, 8-methoxypsoralen, 5-methoxypsoralen, oxypeucedanin and isopimpinellin were among the responsible antimicrobial furocoumarins [32]. Essential oil from aerial part of Petroselinum crispum had no antibacterial activity against Listeria innocua, Serratia marcescens and Pseudomonas fluorescens [46]. methanol extract of parsley leaves demonstrated antimicrobial activity Bacillus subtilis, Petroselinum aeruginosa, Staphylococcus epidermidis, Staphylococcus aureus and Saccharomyces cerevisiae in vitro. Coumarins are responsible components for this property [47].

\section{Haematology activity}

Results indicates that the leaf ethanol extract of Petroselinum crispum was hepatotoxic and nephrotoxic at continued oral doses equal to or more than $1000 \mathrm{mg} / \mathrm{kg}$, but no obvious toxicity when used at lowers doses. Therefore, there should be caution in its administration to avoid overdosing [24].

\section{Traditional uses and ethnobotanical reports of petroselinum crispum in different countries}

Iran- Seeds and leaf: Iran- Seeds and leaf are used for- Antimicrobial, antiseptic, antispasmodic and sedative, gastrointestinal disorder and carminative, digestive, astringent, gastrotonic, inflammation, antidote, halitosis, kidney stone and amenorrhoea. Food flavor, exanthema, alphosis, macula, headcool, sniffle, otitis, antitussive, diuretic, kidney stone, hemorrhoid, gastrointestinal disorder, vision performance and dermatitis [4853].

Iraq- leaf: Iraq- leaf is used for- curing skin disease [54].

Turkey- Leaf and Seeds: These are used for- Anticoagulant, hypertension, hyperlipidemia, hepatotoxic, diabetes and diuretic [55-57].

Morocco- leaf: It is used for Arterial hypertension, diabetes, cardiac disease, renal disease, lumbago, high blood pressure, eczema, nose bleed, amenorrhoea, dysmenorrheal and kidney stones [53-57].

Spain- Leaf: It is used for Prostatitis, diabetes, halitosis, anemia, hypertension, hyperuricaemia, constipation, odontalgy, pain and baldness $[17,58,59]$.

Peru- Seed: It is used for Carminative and gastritis [60,61].

Serbia- Leaf: Serbia- Leaf is used for Urinary tract disease, fluid retention and urinary tract infections $[62,63]$.

\section{Contraindications and safe doses of petroselinum crispum}

Harmless and free of toxicity plants and foods are very less available in our time but few herbs are here to cure physical condition and it's proven by different experiments and intervention method and safe does are recommended. The drawbacks of using these solvents are representing their toxicity and therefore cannot be added to foods. Thus, the use of non-toxic solvents and solvent mixtures such as vegetable oils or micro emulsions could be beneficial to soluble the plant extracts and also for adding to foods. Petroselinum crispum safe doses are recommended as 2gm/ $\mathrm{kg}$ bw/day [64-66].

\section{Conclusion}

Petroselinum crispum has been used as an herbal medication since historic period. There is a need for sustain hard work that spotlight on pre-clinical studies with Petroselinum crispum linking animal and human models on different diseases. This may then be as a result validated in clinical trials that will help in developing Petroselinum crispum as a promising therapeutic agent. Therefore, Petroselinum crispum and its parts could be safe and provide bioactive benefits.

\section{References}

1. Trifunschi S, Ardelean D (2012) Quantification of phenolics and flavonoids from Petroselinum crispum extracts. Arad Medical Journal 15(1-4): 83-86.

2. Hostetler GL, Riedl KM, Steven J (2012) Endogenous Enzymes, Heat and $\mathrm{pH}$ Affect Flavone Profiles in Parsley (Petroselinum crispum var. neapolitanum) and Celery (Apium graveolens) during Juice Processing. Schwartz J Agric Food Chem 60(1): 202-208.

3. Rashwan NM (2012) Biological study on the effect of arginine and parsley on renal toxicity in rats. World Journal of Medical Sciences 7(4): 264-269. 
4. Petrolini FVB, Lucarini R, de Souza MGM, Pires RH, Cunha WR, Martins CHG (2013) Evaluation of the antibacterial potential of Petroselinum crispum and Rosmarinus officinalis against bacteria that cause urinary tract infections. Brazilian Journal of Microbiology 44(3): 829-834.

5. Mahmood S, Hussain S, Malik F (2014) Critique of medicinal conspicuousness of parsley (Petroselinum crispum): a culinary herb of Mediterranean region. Pakistan Journal of Pharmaceutical Sciences 27(1): 193-202.

6. Vora SR, Patil RB, Pillai MM (2012) Oxidative stress associated alterations in lysosomal enzymes and modulatory effect of Petroselinum crispum (Mill) nyman ex. a.w. hill leaf extract on mouse brain. AmericanEurasian Journal of Scientific Research 7(2): 64-68.

7. Ozsoy-Sacan O, Yanardag R, Orak H, Ozgey Y, Yarat A, Tunali T (2006) Effects of parsley (Petroselinum crispum) extract versus glibornuride on the liver of streptozotocin induced diabetic rats. Journal of Ethnopharmacology 104(1-2): 175-181.

8. Papay ZE, Kosa A, Boldizsar I, Ruszkai A, Balongh E, Klebovich I, Antal I (2012) Pharmaceutical and formulation aspects of Petroselinum crispum extract. Acta Pharmaceutica Hungarica 82(1): 3-14.

9. Caunii A, Cuciureanu R, Miklósné AZ, Tonea E, Giuchici C (2010) Chemical composition of common leafy vegetables. Studia Universitatis "Vasile Goldiş". Life Sciences Series 20(2): 45-48.

10. Kolarovic J, Popovic M, Zlinská J, Trivic S, Vojnovic M (2010) Antioxidant activities of celery and parsley juices in rats treated with doxorubicin. Molecules 15(9): 6193-6204.

11. Vokk R, Lõugas T, Mets K, Kravets M (2011) Dill (Anethum graveolens L.) and parsley (Petroselinum crispum (Mill) Fuss) from Estonia: seasonal differences in essential oil composition. Agronomy Research 9(2): 515520 .

12. Gogus U, Smith C (2010) n-3 Omega fatty acids: a review of current knowledge. International Journal of Food Science and Technology 45: 417-436.

13. Zhang H, Chen F, Wang X, Yao H-Y (2006) Evaluation of antioxidant activity of parsley (Petroselinum crispum) essential oil and identification of its antioxidant constituents. Food Research International 39(8): 833-839.

14. Mohanty I, Senapati MR, Jena D, Behera PC (2014) Ethnoveterinary importance of herbal galactogogues - a review. Veterinary World 7(5): 325-330.

15. Irzaie NM, Amabi D, Moazedi AA, Seyyednejad SM (2010) The role of $\alpha$ and $\beta$ adrenergic receptors in the spasmolytic effects on rat ileum of Petroselinum crispum latifolium (Parsley). Asian Pacific Journal of Tropical Medicine 3(11): 866-870.

16. Mimica-Dukić, Popović N, Apiaceae M (2007) Species a promising source of pharmacologically active compounds Petrosellinum crispum, Apium greveolens and Pastinaca sativa. Phytopharmacology and Therapeutic Values III 21: 132-133

17. Soliman HA, Eltablawy NA, Hamed MS (2015) The ameliorative effect of Petroselinum crispum (parsley) on some diabetes complications. Journal of Medicinal Plants Studies 3(4): 92-100.

18. Benítez G, González-Tejero MR, Molero-Mesa J (2010) Pharmaceutical ethnobotany in the western part of Granada province (southern Spain) Ethnopharmacological synthesis. Journal of Ethnopharmacology 129(1): 87-105.

19. Rahimi R, Shams-Ardekani MR, Abdollahi M (2010) A review of the efficacy of traditional Iranian medicine for inflammatory bowel disease. World Journal of Gastroenterology 16(36): 4504-4514.

20. EL-Khalaf M, EL-Toukhy S (2013) Modulatory effect of parsley and vitamin $C$ in ovalbumin induced asthma in mice. Australian Journal of Basic and Applied Sciences 7(7): 250-258.
21. Sęczyk Ł, Świeca M, Gawlik-Dziki U (2015) Changes of antioxidant potential of pasta fortified with parsley (Petroselinum crispum Mill.) leaves in the light of protein-phenolics interactions. Acta Scientiarum Polonorum Technologia Alimentaria 14(1): 29-36.

22. Farzaei MH, Abbasabadi Z, Ardekani MRS, Rahimi R. Farzaei F (2013) Parsley: A review of ethnopharmacology, phytochemistry and biological activities. Journal of Traditional and Complementary Medicine 33(6): 815-826.

23. Al-Daraji HJ, Al-Mashadani HA, Al-Hassani AS, Mirza HA, Al-Hayani WK (2012) The influence of parsley (Petroselinum crispum) as feed additive on hematological traits of local Iraqi geese. Advances in Nutrition Research 1(1): 1-5.

24. Wright CI, Van-Buren L, Kroner CI, Koning MM (2007) Herbal medicines as diuretics: a review of the scientific evidence. Journal of Ethnopharmacology 114(1): 1-31.

25. Awe EO, Banjoko SO (2013) Biochemical and haematological assessment of toxic effects of the leaf ethanol extract of Petroselinum crispum (Mill) Nyman ex A.W. Hill (Parsley) in rats. BMC Complementary and Alternative Medicine 13(75): 1-6.

26. Allam AA, Ajarem J, Abdul-Hamid M, Bakry A (2013) Acrylamide disrupts the development of medulla oblongata in albino rat: biochemical and morphological studies. Afr J Pharm Pharmacol 7(20): 1320-31.

27. Jassim AM (2013) Protective Effect of Petroselinum crispum (parsley) extract on histopathological changes in liver, kidney and pancreas induced by sodium valproate-in male rats. Kufa J Vet Med Sci 4(1): 2027.

28. Maodaa SN, Allam AA, Ajarem J, Abdel-Maksoud MA, Al-Basher GI, et al. (2016) Effect of parsley (Petroselinum crispum, Apiaceae) juice against cadmium neurotoxicity in albino mice (Mus Musculus). Behavioral and Brain Functions 12(1): 6.

29. Nielsen SE, Young JF, Daneshvar B, Lauridsen ST, Knuthsen P, Sandstrom B, Dragsted LO (1999) Effect of parsley (Petroselinum crispum) intake on urinary apigenin excretion, blood antioxidant enzymes and biomarkers for oxidative stress in human subjects. British Journal of Nutrition 81(06): 447-455.

30. Wong PYY, Kitts DD (2006) Studies on the dual antioxidant and antibacterial properties of parsley (Petroselinum crispum) and cilantro (Coriandrum sativum) extracts. Food Chem 97(3): 505-515.

31. Popović M, Kaurinović B, Jakovljević V, Mimica-Dukic N, Bursać M (2007) Effect of parsley (Petroselinum crispum (Mill.) Nym. ex A.W. Hill, Apiaceae) extracts on some biochemical parameters of oxidative stress in mice treated with CCl(4). Phytotherapy Research 21(8): 717-723.

32. Fejes S, Blázovics A, Lemberkovics E, Petri G, Szoke E, Kéry A (2000) Free radical scavenging and membrane protective effects of methanol extracts from Anthriscus cerefolium L. (Hoffm.) and Petroselinum crispum (Mill.) nym. ex A.W. Hill. Phytotherapy Research 14(5): 362365 .

33. Behtash N, Kargarzadeh F, Shafaroudi H (2008) Analgesic ef fects of seed extract from Petroselinum crispum (Tagetes minuta) in animal models. Toxicol Lett 180(5): S127-S128.

34. Branković S, Kitić D, Radenković M, Ivetić V, Veljković S, Nesić M (2010) Relaxant activity of aqueous and ethanol extracts of parsley (Petroselinum crispum (Mill) Nym. ex A. W Hill, Apiaceae) on isolated ileum of rat. Medicinski Pregled 63(7-8): 475-478.

35. Yousofi A, Daneshmandi S, Soleimani N, Bagheri K, Karimi MH (2012) Immunomodulatory effect of Parsley (Petroselinum crispum) essential oil on immune cells: mitogen-activated splenocytes and peritoneal macrophages. Immunopharmacology and Immunotoxicology 34(2): 303-308.

36. Al-Howiriny T, Al-Sohaibani M, El-Tahir K, Rafatullah S (2003) Prevention of experimentally-induced gastric ulcers in rats by an 
ethanolic extract of "Parsley" Petroselinum crispum. American Journal of Chinese Medicine 31(5): 699-711.

37. Kreydiyyeh SI, Usta J, Kaouk I, Al-Sadi R (2001) The mechanism underlying the laxative properties of Parsley extract. Phytomedicine 8(5): 382-388.

38. Yoshikawa M, Uemura T, Shimoda H, Kishi A, Kawahara Y, Matsuda $\mathrm{H}$ (2000) Medicinal foodstuffs. XVIII. Phytoestrogens from the aerial part of Petroselinum crispum MIll. (Parsley) and structures of 6"-acetylapiin and a new monoterpene glycoside, petroside. Chemical and Pharmaceutical Bulletin 48(7): 1039-1044.

39. Abdel-Wahhab AM, Abbes S, Salah-Abbes JB, Hassan AM, Oueslati R (2006) Parsley oil protects against Zearalenone-induced alteration in reproductive function in male mice. Toxicology Letters 164: S266.

40. Kreydiyyeh SI, Usta J (2002) Diuretic effect and mechanism of action of parsley. J Ethnopharmacol 79(3): 353-357.

41. Brankovic S, Djosev S, Kitic D, Radenković M, Ivetić V, Veljković S, Nešić IM (2008) Hypotensive and negative chronotropic and inotropic effects of the aqueous and ethanol extract from parsley leaves. Journa of Clinical Lipidology 2(5) (Suppl 1): S191, S408.

42. Chaves DS, Frattani FS, Assafim M, de Almeida AP, de Zingali RB, Costa SS (2011) Phenolic chemical composition of Petroselinum crispum extract and its effect on haemostasis. Natural Product Communications 6(7): 961-964.

43. Gadi D, Bnouham M, Aziz M, Ziyyat A, Legssyer A, et al. (2012) Flavonoids purified from parsley inhibit human blood platelet aggregation and adhesion to collagen under flow. Journal of Complementary \& Integrative Medicine 9(1): 19.

44. Gadi D, Bnouham M, Aziz M, Ziyyat A, Legssyer A, et al. (2009) Parsley extract inhibits in vitro and ex vivo platelet aggregation and prolong bleeding time in rats. Journal of Ethnopharmacology 125(1): 170-174.

45. Kim OM, Kim MK, Lee SO, Lee KR, Kim SD (1998) Antimicrobial effect of ethanol extracts from spices against Lactobacillus plantarum and Leuconostoc mesenteroides isolated from kimchi. Journal of the Korean Society of Food Science and Nutrition 27(3): 455-460.

46. Manderfield MM, Schafer HW, Davidson PM, Zottola EA (1997) Isolation and identification of antimicrobial furocoumarins from parsley. Journal of Food Protection 60(1): 72-77.

47. Viuda-Martos M, Mohamady MA, Fernández-López J, Abd ElRazik KA, Omer EAet al. (2011) In vitro antioxidant and antibacterial activities of essentials oils obtained from Egyptian aromatic plants. Food Control 22(11): 1715-1722

48. Ojala T, Remes S, Haansuu P, Vuorela H, Hiltunen R, et al. (2000) Antimicrobial activity of some coumarin containing herbal plants growing in Finland. Journal of Ethnopharmacology 73(1-2): 299-305.

49. Moazedi AA, Mirzaie DN, Seyyednejad SM, Zadkarami MR, Amirzargar A (2007) Spasmolytic effect of Petroselinum crispum (Parsley) on rat's ileum at different calcium chloride concentrations. Pakistan Journal of Biological Sciences 10(22): 4036-4042

50. Aghili MH, Rahimi RMAA, Shams Ardekani MR, Farjadmand F (2009) Tehran: Tehran University of Medical Sciences 329-330.

51. Tonkaboni MM, Tohfeh-al-Momenin Rahimi R, Shams Ardekani MR, Farjadmand F (2007) Tehran: Shahid Beheshti University of Medical Sciences 129.
52. Avicenna (1983) The cannon of medicine, translated from Arabic to Persian by AbdulrahmanSharaf-kandi. Tehran: Sorush Publication 141.

53. Aljanaby AAJJ (2013) Antibacterial activity of an aqueous extract of Petroselinum crispum leaves against pathogenic bacteria isolated from patients with burns infections in Al-najaf Governorate, Iraq. Res Chem Intermed 39(8): 3709-3714.

54. Oztürk Y, Baser CHK, Aydın S (1991) Hepatoprotective (antihepatotoxic) plants in Turkey Proceedings of the 9th Symposium on Plant Drugs. Baser KHC (Ed). Eskisehir: Turkey 40-50.

55. Bolkent S, Yanardag R, Ozsoy-Sacan O, Karabulut-Bulan O (2004) Effects of parsley (Petroselinum crispum) on the liver of diabetic rats: a morphological and biochemical study. Phytotherapy Research 18(12): 996-999.

56. Ziyyat A, Legssyer A, Mekhfi H, Dassouli A, Serhrouchni M, Benjelloun W (1997) Phytotherapy of hypertension and diabetes in oriental Morocco. Journal of Ethnopharmacology 58(1): 45-54.

57. Eddouks M, Maghrani M, Lemhadri A, Ouahidi ML, Jouad H (2002) Ethnopharmacological survey of medicinal plants used for the treatment of diabetes mellitus, hypertension and cardiac diseases in the south-east region of Morocco (Tafilalet). Journal of Ethnopharmacology 82(2-3): 97-103.

58. Jouad H, Haloui M, Rhiouani H, El Hilaly J, Eddouks M (2001) Ethnobotanical survey of medicinal plants used for the treatment of diabetes, cardiac and renal diseases in the North centre region of Morocco (Fez-Boulemane). Journal of Ethnopharmacology 77(2-3): 175-182.

59. Merzouki A, Ed-Derfoufi F, El-Aallall A, Molero-Mesa J (1997) Wild medicinal plants used by local Bouhmed population (Morocco). Fitoterapia 68(5): 444-460.

60. Montesano V, Negro D, Sarli G, De Lisi A, Laghetti G, Hammer K (2012) Notes about the uses of plants by one of the last healers in the Basilicata Region (South Italy). Journal of Ethnobiology and Ethnomedicine 8: 15

61. Savikin K, Zdunic G, Menković N, Zivković J, Cujić N, Tereščenko M, Bigović D (2013) Ethnobotanical study on traditional use of medicinal plants in South-Western Serbia, Zlatibor district. Journal of Ethnopharmacology 146 (3): 803-810.

62. Marczal G, Balogh M, Verzar-Petri G (1997) Phenol-ether components of diuretic effect in Pseudomonas crispum. Acta Agron Acad Sci Hung 26(1-2): 7-13.

63. Rehecho S, Uriarte-Pueyo I, Calvo J, Vivas AL, Calvo MI (2011) Ethnopharmacological survey of medicinal plants in Nor-Yauyos, a part of the Landscape Reserve Nor-Yauyos- Cochas, Peru. Journal of Ethnopharmacology 133(1): 75-85.

64. Meyer H, Bolarinwa A, Wolfram G, Linseisen J (2006) Bioavailability of apigenin from apiin-rich parsley in humans. Annals of Nutrition and Metabolism 50(3): 167-172.

65. Griffiths IB, Douglas RGA (2000) Phytophotodermatitis in pigs exposed to parsley (Petroselinum crispum). Vet Rec 146(3): 73-74.

66. Chaudhary SK, Ceska O, Têtu C, Warrington PJ, Ashwood-Smith MJ, et al. (1986) Oxypeucedanin, a major furocoumarin in Parsley (Petroselinum crispum). Planta Medica 52(6): 462-464. 
This work is licensed under Creative Commons Attribution 4.0 License DOI: 10.19080/JCMAH.2018.07.555707

\section{Your next submission with Juniper Publishers} will reach you the below assets

- Quality Editorial service

- Swift Peer Review

- Reprints availability

- E-prints Service

- Manuscript Podcast for convenient understanding

- Global attainment for your research

- Manuscript accessibility in different formats

( Pdf, E-pub, Full Text, Audio)

- Unceasing customer service

Track the below URL for one-step submission https://juniperpublishers.com/online-submission.php 